\title{
Informal Kinship Care Most Common Out-of- Home Placement After an Investigation of Child Maltreatment
}

$\mathrm{T}$ his fact sheet examines differences between urban and rural areas in foster care placement with informal kin caregivers. Kin care placement can be beneficial for children because they already know the caregivers and therefore have more placement stability. However, informal kin caregivers often receive fewer services, including financial assistance, than other types of substitute caregivers. ${ }^{1}$ Some kin caregivers prefer an informal placement because they do not want to upset the parent or weaken family relationships with them; sometimes they also distrust the protective agency or fear that the child will be removed from their home. But other kin caregivers would rather have the financial benefits-and Medicaid coverage for the child-associated with formal placement.

All fifty states, the District of Columbia, and U.S. Territories have mandatory child abuse and neglect reporting laws that require certain professionals and institutions to report suspected maltreatment to a child protective services (CPS) agency. In 2011, CPS investigated reports on 3 million children. ${ }^{2}$ When CPS has concerns about a child's safety, it places the child in a substitute care arrangement, such as foster care, formal kinship care (in which case the state has legal custody and places the child with a family member), informal kinship care (a parent voluntarily places a child with a family member ${ }^{3}$ ), or group homes or other out-ofhome settings, such as emergency shelters or residential programs. We examine whether there are differences in the placement patterns across rural and urban settings both immediately and 18 months after initial placement.

The data for this analysis come from a national sample of children who had a maltreatment report that resulted in an investigation: the second National Survey of Child and Adolescent Well-Being (NSCAW II). The NSCAW II cohort includes 5,873 children, aged birth to 17.5 years old, who had contact with the child welfare system within a 15-month period beginning in February 2008. Followup data were collected approximately 18 months later (October 2009 to January 2011). ${ }^{4}$

\begin{abstract}
Key Findings
Informal kinship placement settings, where a parent voluntarily places a child with a family member, were the most common out-of-home placement in both rural and urban areas. Informal placements involve children who are in physical custody of a relative but may remain in legal custody of a parent.

- $\quad$ Children aged 3 to 5 with a child maltreatment report in rural areas and those in very poor rural households (incomes less than 50 percent of federal poverty level) were more likely to be in informal kinship settings than similar children in urban areas.
\end{abstract}

\section{Placement Settings}

After the initial child maltreatment investigation, the vast majority of children remained in their home ( 88 percent in rural areas and 87 percent in urban areas). Among those who were placed in out-of-home settings, informal kinship care was the most common. In rural areas, 47 percent of children with a child maltreatment report and placed outof-home were with informal kin. Eighteen months later, of those children placed out-of-home, 65 percent were with informal kin. In urban areas, 49 percent of children placed out-of-home were with informal kin, and 18 months later, 54 percent were with informal kin (see Figure 1).

\section{Child Age and Placement}

Children with a maltreatment report were most likely to remain in their home regardless of child age ( 0 to 2,3 to 5,6 to 10,11 to 17). Between 5 and 18 percent of children in each age group were in informal kinship care. The only significant placement

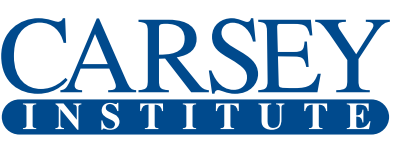

BuILding KNOWLEDGE FOR FAmilies AND Communities
Huddleston Hall, 73 Main Street, Durham, NH 03824

(603) 862-2821 • www.carseyinstitute.unh.edu

This work was supported by the Annie E. Casey Foundation, the W. K. Kellogg Foundation, and anonymous donors. 


\section{Figure 1. OUt-OF-HOME PLACEMENT SETtings AFTER MALTREATMENT REPORT AND 18 MONTHS LATER}

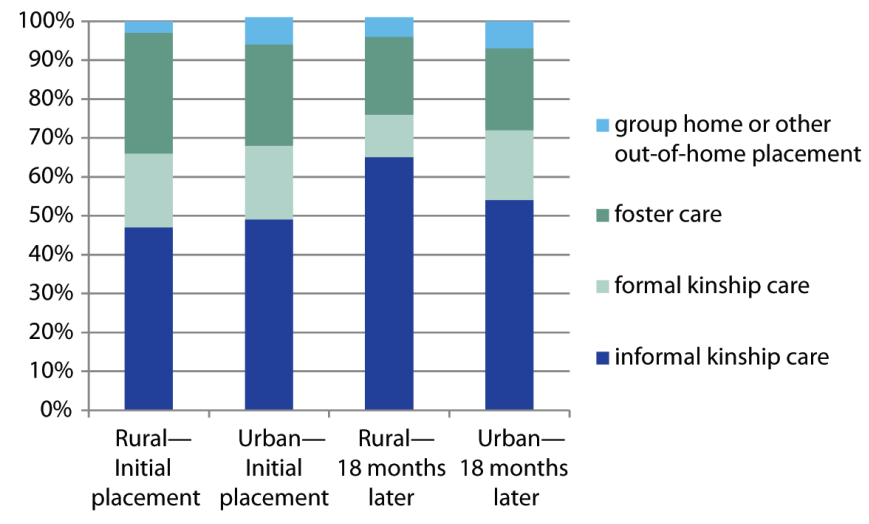

difference between rural and urban areas was that a larger percentage of children aged 3 to 5 were in informal kinship care in rural areas (18 percent) than in urban areas ( 6 percent). ${ }^{5}$

\section{Poverty and Placement}

Children with a maltreatment report were most likely to remain in their home regardless of poverty status or the depth of poverty (for example, less than 50 percent, 50-99 percent, 100-200 percent, or greater than 200 percent of the federal poverty level [FPL]). However, children in very poor households (less than 50 percent of the FPL) in rural areas were significantly more likely to be placed with informal kinship care (13 percent) than those in urban areas (4 percent). Children in very poor households in urban areas were more likely to remain in their homes (93 percent) than were those in rural areas (82 percent).

\section{Understanding Informal Kinship Care}

The findings highlight the need to pay attention to the role of kinship care in placement decisions. The growing use of informal kinship care follows the federal guidelines emphasizing a preference for kin caregivers. The Adoption and Safe Families Act of 1997 (P.L. 105-89), for example, states that when making placement decisions, preference is given to adult relatives over nonrelative caregivers. Research also finds less placement disruption in kinship care. ${ }^{6}$ Our findings point to the need to develop ways to better support informal kin, especially among very poor households. Although kin caregivers play an important role in caring for maltreated children, they are less likely to receive services, including financial assistance, than other types of substitute caregivers. ${ }^{7}$ In many states, innovative models, such as the Kinship Navigator program, are emerging to help kinship caregivers access supports and services. ${ }^{8}$ Programs should continue to develop comprehensive access to community based and government services, such as access to stable housing, affordable legal representation, and financial assistance, in order to better support kinship families. ${ }^{9}$

\section{E N D N O T E S}

1. G. S. Cuddeback, "Kinship Family Foster Care: A Methodological and Substantive Synthesis of Research," Children and Youth Services Review, vol. 26 (2004): 623-639; H. Dubowitz, S. Feigelman, and S. Zuravin, "A Profile of Kinship Care," Child Welfare, vol. 72 (1993): 153-169.

2. U.S. Department of Health and Human Services, Child Maltreatment 2011 (Washington, DC: DHHS, Administration for Children and Families, Administration on Children, Youth, and Families, Children's Bureau, 2012), available at www.acf.hhs.gov/programs/cb/research-data-technology/statistics-research/child-maltreatment.

3. In some cases, children may be placed with informal kin because of a court order. Informal kinship care covers a wide variety of circumstances and varies by state. However, usually the children are in the physical custody of the relatives, but they may remain in the legal custody of the parents. Child Welfare Information Gateway, "Kinship Caregivers and the Child Welfare System" (Washington, DC: Child Welfare Information Gateway, 2010), available at www.childwelfare.gov/pubs/f_kinshi/f_kinshi.pdf.

4. For information on the NSCAW II study design and sampling procedure, see M. Dolan et al., NSCAW II Baseline Report: Introduction to NSCAW II Final Report, OPRE Report \#2011-27a (Washington, DC: DHHS, Office of Planning, Research and Evaluation, Administration for Children and Families, 2011), available at www.acf.hhs.gov/programs/opre/index.html.

5. Cell sizes are small $(n=16)$ for some of the cells, and differences between groups may be statistically significant with a larger sample size. Analyses for age and poverty and placement combine all types of foster care (that is, foster care, formal kinship care, and group homes).

6. A. S. Jones and S.J. Wells, "PATH/Wisconsin-Bremer Project: Preventing Placement Disruptions in Foster Care: Final Report" (Minneapolis: University of Minnesota, 2008), available at www. cehd.umn.edu/ssw/G-S/ media/Final_report.pdf; J. Park and J. Helton, "Transitioning from Informal to Formal Substitute Care Following Maltreatment Investigation," Children and Youth Services Review, vol. 32 (2010): 998-1003.

7. Cuddeback, "Kinship Family Foster Care"; Dubowitz et al., "A Profile of Kinship Care."

8. Public Children Services Association of Ohio, Ohio's Fostering Connections Grant: Enhanced Kinship Navigator Project (Columbus, OH: Public Children Services Association of Ohio, 2012), available at http://www. kinshipohio.org/Resources/2012/Kin\%20Navigator\%20Grant\%20Final\%20 Overivew\%20Conclusions\%20Recommendations_December2012.pdf.

9. The Annie E. Casey Foundation, Stepping Up for Kids What Government and Communities Should Do to Support Kinship Families (Baltimore, MD: The Annie E. Casey Foundation, 2012), available at http://www.aecf.org/ / media/Pubs/Initiatives/KIDS\%20COUNT/S/SteppingUpforKids2012PolicyReport/SteppingUpForKidsPolicyReport2012.pdf.

\section{A B OUT THE AUTHOR}

Wendy A. Walsh is a research associate professor of sociology at the Crimes against Children Research Center and a research associate at the Carsey Institute at the University of New Hampshire (wendy.walsh@unh.edu).

\section{A C K N O W L E D G M E N T S}

We are grateful for the substantive and editorial comments and suggestions from Bruce Mallory, Curt Grimm, Marybeth Mattingly, Amy Sterndale, and Laurel Lloyd at the Carsey Institute and Barbara Ray at Hired Pen.

This document includes data from the National Survey on Child and Adolescent Well-Being, which was developed under contract with the Administration on Children, Youth, and Families, U.S. Department of Health and Human Services (ACYF/DHHS). The data have been provided by the National Data Archive on Child Abuse and Neglect. The information and opinions expressed herein reflect solely the position of the authors. Nothing herein should be construed to indicate the support or endorsement of its content by ACYF/DHHS. 